\title{
PENERAPAN METODE ROLEPLAYING DALAM PENINGKATAN KETERAMPILAN GERAK SHALAT ANAK TK AL-LATIF KECAMATAN TAMBANG KABUPATEN KAMPAR
}

\author{
Joni \\ Universitas Pahlawan, Indonesia \\ joni_bengkulu@yahoo.com
}

\begin{abstract}
ABSTRAK
Peneliti melihat bahwa pembelajaran gerak shalat belum begitu menjadi perhatian serius oleh para pengajar TK Al-Latif, Kecamatan Tambang, Kabupaten Kampar sehingga ketuntasan belajar belum tercapai, sementara itu pembelajaran shalat pertama adalah pembelajaran gerak shalat bukan pembelajaran bacaan, hakekat metode role playing terletak pada keterlibatan emosional pemeran dan pengamat dalam situasi masalah yang secara nyata dihadapi melalui bermain peran, masih menurut Mulyasa, E, terdapat empat asumsi yang mendasari pembelajaran bermain peran untuk mengembangkan perilaku dan nilai-nilai sosial, yang kedudukannya sejajar dengan model-model mengajar lainnya Metode penelitian yang digunakan adalah eksperimen model desain control group pre-test-post-test (Arikunto, S 2006:86). Model tersebut bertujuan untuk mengetahui dan membandingkan data hasil nilai sebelum dan sesudah perlakuan pada subjek yang sama. Di dalam desain ini observasi dilakukan sebanyak 2 kali yaitu sebelum eksperimen dan sesudah eksperimen. Observasi yang dilakukan sebelum eksperimen $\left(\mathrm{O}_{1}\right)$ disebut pre-test, dan observasi sesudah eksperimen $\left(\mathrm{O}_{2}\right)$ disebut post-test. Penelitian dilakukan dengan dua kelompok sampel yaitu kelompok eksperimen dan kelompok kontrol. Hasil uji secara statistik terhadap keterampilan shalat dengan metode role playing pada anak TK saat pretest dengan posttest menunjukkan perbedaan yang signifikan ( $\mathrm{p}$-value $=0,000<0,05$ ). Hasil pengujian ini menunjukkan bahwa terdapat perubahan yang signifikan pada keterampilan shalat dengan metode role playing pada anak TK setelah mendapat perlakuan. Terdapat perubahan yang signifikan pada keterampilan melakukan gerak shalat melalui metode role playing, sehingga metode ini dapat digunakan dalam keterampilan melakukan gerak shalat di TK Al-latif Kecamatan Tambang adapun Permasalahan yang ditemukan Guru TK masih kaku dan mengalami kecanggungan dalam menerapkan metode role playing, siswa belum dapat memahami instruksi guru dengan benar dalam peran yang akan dimainkan oleh anak. Adapun yang menjadi rekomendasi sebagai berikut: Kepada Guru TK, bahwa dalam penerapan metode role playing harus melaksanakan semua tahapan penerapan sehingga akan memudahkan guru dalam mencapai tujuan pembelajarannya, terutama dalam keterampilan melakukan gerak shalat
\end{abstract}




\section{PENDAHULUAN}

Dalam Agama Islam shalat merupakan ibadah wajib yang harus dilakukan oleh setiap orang yang telah mencapai akil baliq, yang juga merupakan rukun Islam kedua setelah mengucapkan kalimat syahadat. Begitu agung kedudukannya di dalam Islam hingga Rasulullah SAW menyebutnya sebagai pilar agama Islam.

Shalat berasal dari bahasa Arab yaitu As-Sholah adapun pengertian Shalat secara bahasa (etimologi) berarti do'a, sebagaimana tertera dalam surat AtTaubah ayat ke 103, sedangkan secara Istilah (terminologi) shalat adalah perkataan dan perbuatan khusus yang dimulai dengan takbir (takbiratul ihram) diakhiri dengan salam.

Rasulullah saw sendiri pernah memperagakan tatacara shalat di atas mimbar agar dapat disaksikan oleh parasa habat. Demikian juga banyak kita dapatkan penukilan dari para sahabat yang memperagakan tatacara shalat kepada tabi'in demikian seterusnya. Hal itu menunjukkan bahwa mempelajari tatacara shalat hukumnya fardhu 'ain, dan mengajarkan tatacara hukumnya fardhu kifayah. Dari tatacarashalat yang diajarkan Rasulullah SAW kepada para sahabat dapat kita ketahui bahwa metode peragaan adalah metode yang sangat praktis dan efisien. Karena itulah Rasulullah saw memakainya. Beliau shalat di atas mimbar untuk memperagakan kepada umat tatacara shalat yang benar dan ternyata hal itu mudah dipahami para sahabat beliau. Terbukti mereka juga memakai cara tersebut untuk mengajarkan tata cara shalat kepada orang yang membutuhkan

Sementara dalil yang mewajibkan shalat banyak sekali, baik dalam Al-qur'an seperti pada Surat Al-baqarah ayat 43 yang artinya "Dan dirikanlah shalat, dan keluarkanlah zakat, dan rukuklah bersama orang-orang yang rukuk" pada surat lain dikatakan juga "Kerjakanlah shalat, sesungguhnya shalat itu mencegah perbuatan yang keji (jahat) dan perbuatan yang mungkar" surat QS. Al-Angkabut ayat 45 dan masih banyak lagi dalil yang bisa kita ditemukan.'

Peneliti melihat bahwa pembelajaran gerak shalat belum begitu menjadi perhatian serius oleh para pengajar TK Al-Latif, Kecamatan Tambang, Kabupaten Kampar sehingga hasilnya pun ketuntasan belajar belum tercapai sesuai dengan ketuntasan klasikal, sementara itu pembelajaran shalat pertama adalah pembelajaran gerak shalat bukan pembelajaran bacaannya, oleh karenanya peneliti mencoba memberikan alternatif pemecahan masalah "Penerapan metode roleplaying dalam peningkatan keterampilan gerak shalat anak TK Al-latif Kecamatan Tambang Kabupaten Kampar"

\section{KAJIAN PUSTAKA}

\section{Keterampilan Geraka Shalat}

1. Pengertian Shalat

Dalam Agama Islam shalat merupakan ibadah wajib yang harus dilakukan oleh setiap orang yang telah mencapai akil baliq, yang juga merupakan rukun Islam 
kedua setelah mengucapkan kalimat syahadah. Begitu agung kedudukannya di dalam Islam hingga Rasulullah SAW menyebutnya sebagai pilar agama Islam.

Shalat berasal dari bahasa Arab yaitu As-Sholah adapun pengertian Sholat secara bahasa (Etimologi) berarti do'a, sebagaimana tertera dalam surah AtTaubah ayat ke 103, sedangkan secara Istilah (Terminologi) shalat adalah perkataan dan perbuatan tertentu/khusus yang dibuka/dimulai dengan takbir (takbiratul ihram) diakhiri/ditutup dengan salam.

Adapun menurut Nuhuyanan, Kadir (2002:19) shalat secara istilah ialah ibadah dalam bentuk perkataan dan perbuatan tertentu dengan menghadirkan hati secara ikhlas dan khusyu, dimulai dengan takbir dan diakhiri dengan salam menurut syarat dan rukun yang telah ditentukan.

Sementara Abbas (1991:2) mengertikan sebagai "at-tadliem" yang berarti mengagungkan karena dalam shalat terdapat pengagungan terhadap rabb (Allah). Shalat merupakan rukun perbuatan yang paling penting diantara rukun Islam yang lain sebab ia mempunyai pengaruh yang baik bagi kondisi akhlak manusia. Shalat didirikan sebanyak lima kali setiap hari, dengannya akan didapatkan pengaruh yang baik bagi manusia dalam suatu masyarakatnya yang merupakan sebab tumbuhnya rasa persaudaraan dan kecintaan diantara kaum muslimin ketika berkumpul untuk menunaikan ibadah yang satu di salah satu dari sekian rumah milik Allah subhanabu wa ta'ala (masjid).

Permasalahan shalat merupakan permasalahan yang sangat penting, khususnya yang berkaitan dengan tata caranya, di samping beberapa permasalahanpermasalahan lain yang berkaitan dengan ibadah yang agung ini, seperti cara berwudhu', kiat shalat dengan khusyu' dan lain-lain. Sehingga Rasulullah SAW memerintahkan kaum muslimin agar mengikuti cara shalat beliau. Dalam sebuah hadist Rasulullah SAW bersabda: "Shalatlah kamu sebagaimana kamu lihat aku shalat" HR. Bukhari, muslim dan ahmad dalam Nasiruddin (2000:46)

Rasulullah saw sendiri pernah memperagakan tata cara shalat di atas mimbar agar dapat disaksikan oleh para sahabat. Demikian juga banyak kita dapatkan penukilan dari para sahabat yang memperagakan tata cara shalat kepada tabi'in demikian seterusnya. Hal itu menunjukkan bahwa mempelajari tata cara shalat hukumnya fardhu 'ain, dan mengajarkan tata cara hukumnya fardhu kifayah. Dari tata cara shalat yang diajarkan Rasulullah saw kepada para sahabat dapat kita ketahui bahwa metode peragaan adalah metode yang sangat praktis dan efisien. Karena itulah Rasulullah saw memakainya. Beliau shalat diatas mimbar untuk memperagakan kepada umat tata cara shalat yang benar. Dan ternyata hal itu mudah dipahami para sahabat beliau. Terbukti mereka juga memakai cara tersebut untuk mengajarkan tata cara shalat kepada orang yang membutuhkan

Sementara dalil yang mewajibkan shalat banyak sekali, baik dalam Al-qur'an seperti pada Surat Al-baqarah ayat 43 yang artinya "Dan dirikanlah shalat, dan keluarkanlah zakat, dan rukuklah bersama orang-orang yang rukuk" pada surat lain dikatakan juga "Kerjakanlah shalat, sesungguhnya shalat itu mencegah perbuatan yang keji (jahat) dan perbuatan yang mungkar" surat QS. Al-Angkabut ayat 45 dan masih banyak lagi dalil yang bisa kita ditemukan.' 
Adapun hadits yang biasanya dijadikan landasan sebagai perintah mengerjakan shalat adalah hadits riwayat $\mathrm{Abu}$ Dawud "perintahkanlah anak-anakmu mengerjakan shalat di waktu usia mereka meningkat 7 tahun, dan pukullah (kalau enggan melakukan shalat) di waktu mereka meningkat usia 10 tahun" dalam

\section{Gerak Shalat}

a. Menghadap kiblat kemudian mengucapkan takbiratul ihram "Allabu Akbar", mengucapkan takbiratul ihram adalah rukun shalat, tidak sah shalat tanpa mengucapkannya. Rasulullah bersabda : “Apabila engkau hendak mengerjakan shalat, maka sempurnakanlah wudhu'mu terlebih dahulu kemudian menghadap kea rah kiblat, lalu ucapkanlah takbiratul ibram" (Muttafaqun 'Alaibi)

b. Mengangkat kedua tangan setentang telinga dengan merapatkan jari jemari. Berdasarkan hadits Malik bin Al-Huwairits bahwa ia berkata: " Rasulullah saw biasa mengangkat kedua tangannya setentang telinga setiap kali bertakbir (di dalam shalat)" (H.R. Muslim)

c. Menggenggam pergelangan tangan kanan serta meletakkannya di atas dada. Berdasarkan hadits riwayat An- Nasa'i yang telah dinyatakan shalih oleh Syaikh Al-Albani, atau meletakkan telapak tangan kanan di atas telapak tangan kiri serta meletakkannya di atas dada. Berdasarkan hadits Waail bin Hujur yang berbunyi: "Lalu Rasulullah saw bersabda (takbiratul Ibram) kemudian meletakkan tangan kanannya di atas telapak tangan kiri, pergelangan tangan kiri lengan kirinya", dan berdasarkan hadits Waail lainnya yang berbunyi " Beliau meletakkan kedua tangannya di atas dadanya".

d. Mengarahkan pandangannya ke tempat sujud

Berdasarkan hadits 'Aisyah r.a mengenai shifat shalat Nabi SAW: "Rasulullah saw tidak mengalihkan pandangannya dari tempat sujud (di dalam shalat) “

e. Rukuk sambil mengucapkan takbir (Allahu Akbar), dengan mengangkat kedua tangan setentang bahu atau telinga. Hendaknya membaca do'a rukuk

f. I'tidal bangkit dari rukuk seraya mengucapkan "Sami'allahi liman hamidah sampai berdiri dengan tegak (HR. Abu Daud dan Hakim)

g. Sujud dilakukan dengan meletakkan 7 anggota badan (dua kaki, dua lutut, dua tangan, kening dan hidung) dan hendaknya merenggangkan jarak antara lengan atas dan rusuknya ketika sujud (HR. Muttafaqun 'alaihi), disunnahkan juga merenggangkan jarak antara perut dan paha, disunnahkan juga merenggangkan jarak antara kedua lutut ketika sujud, sementara telapak kaki yang harus dirapatkan

h. Iftirasy atau gerakan duduk di antara dua sujud yaitu duduk dengan bertumpu di atas telapak kaki kiri dan menegakkan telapak kaki kanan, sementara dibenarkan meletakkan telapak tangan di atas kedua paha atau pada lutut

i. Duduk tasyahud awal yang dimaksud adalah gerakan sama dengan duduk iftirasy dengan meletakkan tangan di atas paha adapun posisi jari kanan adalah sebagai berikut: jari manis dan jari kelingking digenggam, sementara jari tengah ditautkan dengan ibu jari serta mengisyaratkan dengan jari telunjuk saat berdoa atau menggenggam seluruh jari kanan serta mengisyaratkan dengan jari telunjuk saat berdoa dan disetai membaca tahiyat awal. 
j. Duduk tasyahud akhir dilakukan dengan bertawarruk yaitu menegakkan/merebahkan telapak kaki kanan dan mengeluarkan telapak kaki kiri dari bawah betis kaki kanan dengan menjadikan lantai sebagai tempat betelekan, sementara posisi jari kanan sama seperti pada duduk tasyahud awal dan disertai membaca tahiyat akhir.

k. Mengucapkan salam Mengucapkan salam dengan memalingkan wajah ke kanan dan kiri (HR. Muslim)

\section{Metode Role Playing}

Role playing atau bermain peran dalam bahasan ini adalah sebuah metode mengajar, yang menurut Sudjana, N (1989:76) metode mengajar adalah cara yang digunakan dalam mengadakan hubungan dengan anak pada saat berlangsungnya pengajaran.

Menurut Mulyasa, E (2004:141) hakekat pembelajaran melalui bermain peran terletak pada keterlibatan emosional pemeran dan pengamat dalam situasi masalah yang secara nyata dihadapi melalui bermain peran, masih menurut Mulyasa, E, terdapat empat asumsi yang mendasari pembelajaran bermain peran untuk mengembangkan perilaku dan nilai-nilai sosial, yang kedudukannya sejajar dengan model-model mengajar lainnya. Keempat asumsi tersebut sebagai berikut:

Secara implisit bermain peran mendukung suatu situasi belajar berdasarkan pengalaman dengan menitikberatkan isi pelajaran pada situasi "di sini pada saat ini". Para peserta didik dapat menampilkan respon emosional sambil belajar dari respon orang lain, bermain peran memungkinkan para peserta didik untuk mengungkapkan perasaannya yang tidak dapat dikenal tanpa bercermin pada orang lain.

Bermain peran merupakan metode pembelajaran yang dapat dimanfaatkan dalam pelaksanaan pembelajaran. Kemudian bermain peran juga merupakan salah satu bentuk penilaian pendidikan dalam rangka penelaahan perilaku sosial dan nilai sehingga individu menghayati perasaan, sudut pandang dan cara berpikir orang lain serta memperoleh kejelasan atas kedudukan dirinya, demikian menurut Yusuf, S dkk. (1992; 78)

Sementara direktorat pembinaan TK dan SD (2007:6) berpendapat bermain peran dilakukan dengan menciptakan suatu situasi dimana individu diminta untuk melakukan suatu peran tertentu (yang biasanya bukan peran dirinya) di suatu tempat yang tidak biasanya peran tersebut terjadi. Manfaat dari role playing adalah membantu seseorang mengubah sikap atau perilaku dari yang selama ini dilakukan

\section{Kelebihan Metode Role Playing}

Setiap metode memiliki kelebihan yang berbeda dengan metode lainnya, dan di antara kelebihan metode role playing adalah:

1) Peran yang ditampilkan dengan menarik, akan segera mendapat perhatian dari siswa.

2) Dapat digunakan dalam kelompok besar ataupun kecil.

3) Dapat membantu siswa belajar memahami pengalaman.

4) Dapat membantu siswa belajar, untuk menganalisa dan mengalami situasi serta memikirkan masalah yang terjadi dalam peranan itu, Sudjana, Surapradja (2001:136) 


\section{Kelemahan Metode Role Playing}

Metode inipun tidak terlepas dari kelemahan, dan di antara kelemannya adalah:

1) Kemungkinan adanya siswa tidak menyenangi memainkan peranan tertentu.

2) Lebih menekankan terhadap masalah dan pada terhadap peranan.

3) Mungkin akan terjadi kesulitan dalam penyesuaian diri terhadap peran yang harus dilakukan.

4) Membutuhkan waktu lebih lama untuk memerankan sesuatu dalam kegiatan belajar mengajar.

5) Terbatas pada beberapa situasi kegiatan belajar mengajar, Sudjana, Surapradja (2001:136)

\section{Tahap-Tahap Role Playing}

Menurut Shaftel \& Shaftel (dalam Dahlan 1984:128), metode bermain peran terdiri dari sembilan tahapan, yaitu:

1. Memotivasi semangat kelompok.

2. Memilih peranan.

3. Mempersiapkan pengamat.

4. Mempersiapkan tahap-tahap peran.

5. Pemeranan.

6. Mendiskusikan dan mengevaluasi peran dan sisinya.

7. Pemeranan ulang.

8. Mendiskusikan dan mengevakuasi pemeranan ulang.

9. Mengkaji kemanfaatannya dalam kehidupan nyata melalui saling tukar pengalaman dan penarikan generalisasi.

\section{Manfaat Role Playing}

Penggunaan bermain peran dalam pembelajaran sebagai usaha untuk menciptakan kondisi proses pengajaran yang lebih efektif sehingga meningkatkan hasil belajar peserta didik dan menambah aktifitas belajar peserta didik.

Manfaat bermain peran, dikemukakan oleh Yusuf. S dkk (1992; 78) yaitu sebagai berikut;

a. Menghayati suatu kejadian yang sebenarnya merupakan realitas kehidupan.

b. Memahami sebab akibat suatu peristiwa.

c. Mempertajam kepekaan indera fisik dan psikis para peserta didik atas suatu problem kehidupan manusia.

d. Penyaluran/pelepasan ketegangan perasaan-perasaan peserta didik.

e. Sebagai alat pendiagnosis kemampuan dan kebutuhan siswa.

f. Pembentukan konsep diri.

g. Menggali peran-peran manusia dalam suatu kehidupan.

h. Menggali dan menelaah nilai-nilai serta peranan budaya dalam kehidupan antar budaya.

i. Membantu siswa dalam mengklasifikasikan, mengklarifikasikan pola pikir, berbuat dan terampil dalam mengambil keputusan sendiri.

j. Media pembinaan struktur sosial dan sistem nilai selengkapnya.

k. Membina siswa dalam kemampuan memecahkan masalah, berpikir kritis dan analitis, berkomunikasi dan hidup dalam kelompok. 
1. Melatih siswa kearah pengendalian dan pembaharuan perasaan cara berfikir dan pembuatannya.

Untuk dapat mengukur sejauh mana bermain peran memberikan manfaat pada pemeran dan pengamatnya ditentukan oleh tiga hal, yakni (1) kualitas pemeranan, (2) analisis yang dilakukan melalui diskusi setelah pemeranan, (3) persepsi peserta didik terhadap peran yang ditampilkan dibandingkan dengan situasi.

\section{METODE PENELITIAN}

\section{A. Desain Penelitian}

Penelitian ini menggunakan pendekatan kuantitatif, sedangkan metode penelitian digunakan kuasi eksperimen (semu). Metode kuasi eksperimen dipandang relevan digunakan karena memiliki ciri: (1) terpusat pada pemecahan masalah yang aktual, dan (2) data yang dikumpulkan mula-mula disusun, dijelaskan, kemudian dianalisis. Selain itu penelitian kuasi eksperimen banyak digunakan dalam bidang pendidikan atau bidang lain yang subjek penelitiannya adalah manusia yang tidak dapat dimanipulasi dan dikontrol secara intensif (Syamsuddin dan Damaianti, 2006:23).

Dalam penelitian yang menggunakan metode kuasi eksperimen ini, penelitian dilakukan terhadap kelas eksperimen yang menggunakan formula yakni penggunaan metode role playing dalam proses pembalajaran terutama melakukan gerak shalat.

Metode penelitian eksperimen yang digunakan adalah model desain control group pre-test-post-test (Arikunto, S 2006:86). Model tersebut bertujuan untuk mengetahui dan membandingkan data hasil nilai sebelum dan sesudah perlakuan pada subjek yang sama. Di dalam desain ini observasi dilakukan sebanyak 2 kali yaitu sebelum eksperimen dan sesudah eksperimen. Observasi yang dilakukan sebelum eksperimen $\left(\mathrm{O}_{1}\right)$ disebut pre-test, dan observasi sesudah eksperimen $\left(\mathrm{O}_{2}\right)$ disebut post-test. Penelitian dilakukan dengan dua kelompok sampel yaitu kelompok eksperimen dan kelompok kontrol. Dalam eksperimen ini akan dilihat perbedaan pencapaian antara kelompok eksperimen (O2 - O1) dengan pencapaian kelompok kontrol (O4 - O1). Model penelitian tersebut digambarkan sebagai berikut.

$$
\begin{array}{cccc}
\mathrm{E} & \mathrm{O}_{1} & \mathrm{X} & \mathrm{O}_{2} \\
\mathrm{~K} & \mathrm{O}_{2} & & \mathrm{O}_{4}
\end{array}
$$

Keterangan:

E adalah kelompok eksperimen

$\mathrm{K}$ adalah kelompok kontrol

$\mathrm{O}_{1}=$ pemberian tes awal (pre-test)

$\mathrm{X}=$ perlakuan dengan model pembelajaran

$\mathrm{O}_{2}=$ pemberian tes akhir (post-test)

Rumus yang digunakan untuk menghitung efektivitas perlakuan (treatment) adalah:

$$
t=\frac{\text { Md }}{\sqrt{\frac{\sum x^{2} d}{N(N-1)}}}
$$


Keterangan:

$\mathrm{Md}:$ mean dari deviasi (d) antara post-test dan pre-test

$\mathrm{xd}$ : perbedaan deviasi dengan mean deviasi

$\mathrm{N}$ : banyaknya subjek

Df : atau db adalah N-1 (Arikunto, 2006:85-86)

Penelitian ini menggunakan satu kelompok subjek. Pertama dilakukan pengukuran $\left(\mathrm{O}_{1}\right)$, dilakakan perlakuan $(\mathrm{X})$ dalam jangka waktu tertentu, kemudian dilakukan pengukuran $\left(\mathrm{O}_{2}\right)$ untuk kedua kalinya. Pengukuran yang dilakukan menggunakan instrumen yang sama yaitu pengembangan sopan santun dan keterampilan melakukan gerak shalat melalu metode role playing

\section{B. Variabel dan Definisi Operasional Penelitian}

1. Variabel penelitian

Penelitian ini adalah penelitian eksperimen semu yang terdiri dari tiga variabel yaitu satu variabel bebas dan dua variabel terikat. Variabel bebas adalah metode role playing $(\mathrm{X})$, variabel terikat yaitu keterampilan melakukan gerak shalat $(\mathrm{Y})$.

2. Definisi operasional

Untuk menghindari penafsiran yang berbeda-beda tentang istilah yang digunakan dalam penelitian ini maka perlu dijelaskan beberapa istilah teknis yang berhubungan dengan judul penelitian, yaitu:

1. Keterampilan melakukan gerak shalat adalah kecakapan dalam melakukan gerak shalat yang sesuai dengan tuntunan shalat.

2. Metode role playing adalah suatu proses belajar di mana siswa melakukan sesuatu yang dilakukan oleh orang lain. orang lain itu mungkin seorang presiden, raja, menteri, dokter, tokoh masyarakat, pejabat, guru atau bahkan masyarakat biasa (Hasan ; 1996)

\section{Lokasi dan Sumber Data Penelitian}

Penelitian dilakukan di TK Al-latif kecamatan Tambang Kabupaten Kampar. TK TK Al-latif memiliki visi mempersiapkan generasi Islam yang beriman dan bertaqwa kepada Allah SWT dan menjadikan Al Qur'an sebagai pedoman hidupnya, berakhlak mulia, cerdas, terampil, serta punya rasa tanggung jawab dan cinta tanah air

Adapun misinya membantu mewujudkan pendidikan agama islam di sekolah formal dan membantu peran orangtua dirumah, melaksanakan proses pembelajaran shalat dengan benar sebagai tiang agama, serta dapat mengamalkan ajaran-ajaran Islam dan menguasai hapalan-hapalan do'a surat-surat pendek dalam kehidupan sehari-hari melalui pembiasaan.

\section{D.Teknik Pengumpulan Data}

Untuk memperoleh data yang relevan dan sesuai dengan kebutuhan yang berkaitan dengan penelitian, maka diperlukan teknik pengumpulan data yang sesuai dengan tujuan penelitian. Teknik pengumpulan data yang digunakan adalah sebagai berikut:

1. Observasi 
Obeservasi dilakukan dengan melakukan pengamatan secara langsung ke objek penelitian untuk mengamati kondisi nyata objek yang diteliti.

2. Wawancara

Wawancara dilakukan terhadap guru yang terlibat dalam pelaksanaan pembelajaran dengan menerapkan metode role playing untuk memperoleh tanggapan dan umpan balik dari pelakasanaan kegiatan pembe-lajaran.

Pedoman instrumen dibuat sebagai acuan pembelajaran bagi guru dalam penerapan metode role playing berisi: 1) satuan kegiatan harian (SKH), 2) lembar pedoman wawancara, dan 3) pedoman penilaian.

3. Dokumentasi

Mengkaji dokumentasi yang berkenaan dengan proses pembelajaran di TK Allatif, Kecamatan Tambang, Kabupaten Kampar seperti; kurikulum, SKH, SKM dan sebagainya.

\section{E. Teknik Analisis Data}

Data yang diperoleh dalam penelitian ini berupa skor-skor yang diperoleh siswa pada pretes dan postes. Untuk melakukan analisis data dilakukan langkah-langkah sebagai berikut:

1. Memberi skor pada setiap item penelitian pada siswa sesuai dengan kunci dan sistem penskoran yang digunakan.

2. Membuat tabel yang berisikan skor hasil pretes dan postes pada kelas eksperimen.

3. Menghitung rata-rata skor pretes dan postes pada kelas eksperimen dengan menggunakan rumus:

$$
\bar{X}=\frac{\sum X_{i}}{n}
$$

4. Menghitung standar deviasi skor hasil pretes dan skor hasil postes kelas eksperimen dengan menggunakan rumus:

$$
S=\sqrt{\frac{\sum\left(X_{i}-\bar{X}\right)^{2}}{n-1}}
$$

5. Melakukan uji normalitas data skor pretes dan postes untuk mengetahui apakah data berdistribusi normal atau tidak.

6. Melakukan uji homogenitas varians dari skor pretes dan postes untuk mengetahui tingkat kehomogenan distribusi populasi data tes.

7. Melakukan uji perbedaan rata-rata untuk menuji kesignifikansian perbedaan rata-rata hasil pretes dan postes kelas eksperimen.

\section{F. Prosedur Penelitian}

Prosedur penelitian meliputi langkah-langkah sebagai berikut:

1. Melakukan observasi pendahuluan melalui wawancara dengan guru TK yang bersangkutan tentang metode-metode pembelajaran yang selama ini dipakai 
2. Menyepakati dengan guru tentang pelaksanaan pembelajaran dengan menerapkan metode role playing dalam mengembangkan sopan santun dan keterampilan melakukan gerak shalat

3. Melakukan uji validitas instrumen.

Dalam suatu penelitian, data merupakan hal yang paling penting karena data merupakan penggambaran variabel yang diteliti dan berfungsi sebagai alat pembuktian hipotesis yang akan menjadi kesimpulan penelitian. Oleh karena itu hasil penelitian tergantung pada kualitas atau benar tidaknya data. Di sisi lain, kualitas data penelitian ditentukan oleh kualitas instrumen yang digunakan untuk mengumpulkan data. Untuk menguji kualitas instrumen penelitian dilakukan uji validitas dan reliabilitas alat pengumpul data. Valid dan reliabelnya alat pengumpul ditetapkan berdasarkan kriteria sebagai berikut.

Tabel 3.1

Standar Penilaian Untuk Validitas dan Reliabilitas

\begin{tabular}{lll}
\hline Criteria & Reliability & Validity \\
\hline Good & 0,80 & 0,50 \\
Acceptable & 0,70 & 0,30 \\
Marginal & 0,60 & 0,20 \\
Poor & 0,50 & 0,10 \\
\hline
\end{tabular}

Sumber: Barker et al, 2002; 70

4. Memberikan pretes kepada kelas eksperimen.

5. Memperkenalkan motode role playing dan memberikan pelatihan kepada guru yang akan melaksanakan strategi pembelajaran.

6. Pemberian perlakuan kepada kelas eksperimen melalui melalui metode role playing peningkatan keterampilan melakukan gerak shalat anak

7. Memberikan posttest kepada kelas eksperimen keterampilan melakukan gerak shalat

8. Menggunakan uji beda setelah sebelumnya dilakukan pengujian normalitas dan homogenitas variabel data yang ada untuk menguji adakah perbedaan tingkat keterampilan shalat

Data yang diperoleh dalam penelitian ini berupa skor-skor yang diperoleh siswa pada pretes dan postes. Untuk melakukan analisis data dilakukan langkah-langkah sebagai berikut:

a) Menguji distribusi sampel berdasarkan skor hasil pre-tes kelompok eksperimen dan kelompok kontrol dengan menggunakan uji Kolmogorov-Smirnov. Uji normalitas data dilakukan untuk menentukan jenis statistik yang akan digunakan, apakah statistik parametrik atau statistik nonparametrik. Pengujian normalitas data menggunakan test of normality Kolmogorov-Smirnov dengan bantuan program SPSS.

Menurut Singgih Santoso (2002;393), dasar pengambilan keputusan bisa dilakukan berdasarkan nilai probabilitas (asymtotic significance), yaitu: 
- Jika nilai probabilitas $>0,05$ maka distribusi dari data memenuhi asumsi normalitas.

- Jika nilai probabilitas < 0,05 maka distribusi dari data tidak memenuhi asumsi normalitas

\section{G. Alat Test Statistik}

Jenis analisis statistika yang digunakan untuk menguji perbedaan perlakuan yang diberikan tergantung dari hasil pengujian normalitas data. Pada uji antar kelompok (eksperimen dan kontrol), apabila data dari variabel yang sedang diuji berdistribusi normal, maka digunakan statistik parametrik yaitu uji t sampel independen, sebaliknya apabila data dari variabel yang sedang diuji tidak berdistribusi normal, maka digunakan statistik nonparametrik, yaitu uji MannWhitney.

Statistik uji parametrik yang digunakan untuk menguji perbedaan antara kelompok eksperimen dengan kelompok kontrol adalah uji t sampel independen dengan rumus sebagai berikut.

$$
t=\frac{\bar{x}_{1}-\bar{x}_{2}}{s \sqrt{\frac{1}{n_{1}}+\frac{1}{n_{2}}}}
$$

$\mathrm{S}_{\mathrm{D}}=$ Deviasi standar (standar deviation)

(Cooper \& Schindler, 2006:514)

Kriteria pengujiannya adalah :

Tolak Ho jika $|\mathrm{t}|>\mathrm{t}_{\propto}$

Atau tolak Ho jika nilai probabilitas (nilai-p) $<0,05$

- Jika data tidak berdistribusi normal maka rumus yang digunakan Wilcoxon signed rank test dengan rumus sebagai berikut:

$$
z=\frac{T-u_{T}}{\sigma_{T}}
$$

\section{Keterangan:}

$\mathrm{T}=$ jumlah rank dengan tanda paling kecil

$$
u_{T}=\frac{n(n+1)}{4} \text { dan } \quad \sigma_{T}=\sqrt{\frac{n(n+1)(2 n+1)}{24}}
$$

(Cooper \& Schindler, 2006:667)

Kriteria pengujiannya adalah :

Tolak Ho jika $|z|>z_{\propto}$ 
Atau tolak Ho jika nilai probabilitas (nilai-p) $<0,05$

1. Melakukan analisis data hasil observasi.

2. Menarik kesimpulan dari hasil penelitian

\section{PEMBAHASAN TEMUAN}

Sebetulnya dalam penerapan metode role playing ada 9 tahapan dalam penerapan metode role playing seperti yang dikatakan Shaftel \& Shaftel (dalam Dahlan 1984:128), di antara tahapan tersebut yakni: memotivasi semangat kelompok, memilih peranan. mempersiapkan pengamat, mempersiapkan tahaptahap peran. pemeranan, mendiskusikan dan mengevaluasi peran, pemeranan ulang, mendiskusikan dan mengevaluasi pemeranan ulang, mengkaji kemanfaatannya dalam kehidupan nyata melalui saling tukar pengalaman dan penarikan generalisasi.

Dari sekian langkah tahapan tersebut tidak semuanya dilakukan oleh guru TK di antaranya adalah: mendiskusikan dan mengevaluasi peran hal ini dikarenakan oleh usia anak TK yang belum memungkinkan untuk diajak berdiskusi, dan sebagai ganti adalah tanyajawab akan peran yang baru saja anak-anak saksikan, lalu guru meng evaluai jika dilihat bahwa peran yang baru dilakukan kurang tepat

Selain itu tahapan mengkaji kemanfaatannya dalam kehidupan nyata melalui saling tukar pengalaman dan penarikan generalisasi, hal ini dikarenakan tingkat perkembangan anak yang belum memungkinkan untuk diajak mengkaji. Adapun sebagai gantinya adalah guru menyampaikan akan pentingnya membiasakan atau memperaktektan peran yang baru saja meraka saksikan.

Perlu juga diperhatikan bahwa keberhasilan ditentukan oleh tiga hal, yakni (1) kualitas pemeranan, (2) analisis yang dilakukan melalui diskusi setelah pemeranan, (3) persepsi peserta didik terhadap peran yang ditampilkan dibandingkan dengan situasi, sebagaimana yang dikatakan oleh Mulyasa. E (2004:142)

Perubahan Keterampilan Melakukan Gerak Shalat melalui metode role playing pada Anak TK Al-latif, Kecamatan Tambang, Kabupaten Kampar, Keterampilan Melakukan Gerak Shalat Melalui Metode Role Playing.

Terdapat perubahan keterampilan shalat setelah mendapat pembelajaran dengan metode role playing, yang berarti terdapat pengaruh perlakuan terhadap perubahan keterampilan melakukan gerak shalat. Berikut gambaran data pretest dan posttest mengenai keterampilan shalat dengan metode role playing pada kelompok eksperimen anak TK

Gambar 4.10 Nilai Rata-Rata Skor Pretest dan Posttest Keterampilan Melakukan Gerak Shalat 


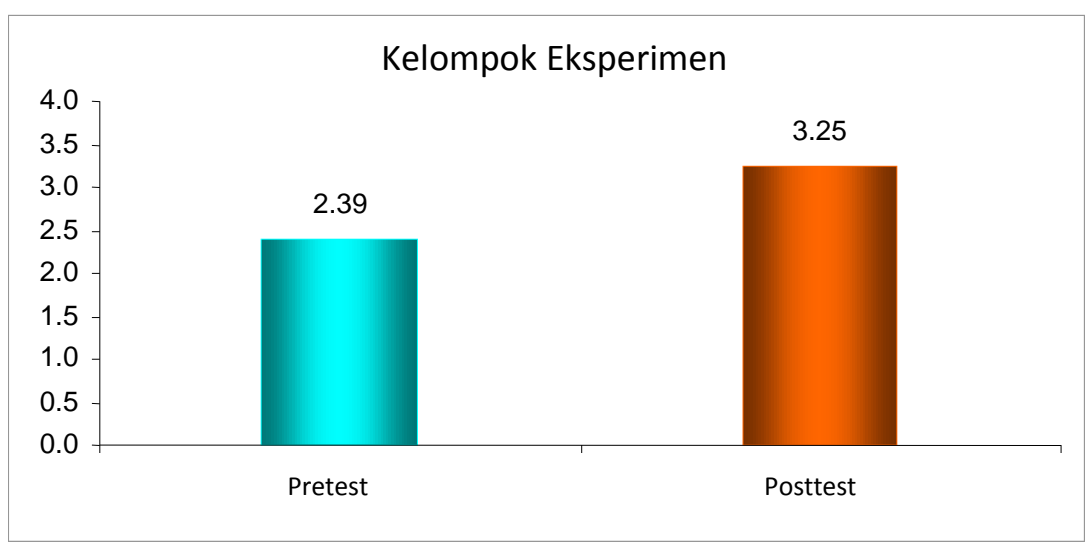

Pada gambar diatas dapat dilihat bahwa rata-rata skor pretest dengan posttest keterampilan shalat dengan metode role playing pada anak TK kelompok eksperimen jauh berbeda. Selanjutnya dilakukan pengujian untuk mendapatkan kesimpulan yang lebih eksak atas hasil deskriptif tersebut. Sesuai dengan hasil uji normalitas data maka untuk menguji perbedaan skor keterampilan shalat dengan metode role playing pada anak TK menggunakan uji t sampel berpasangan.

Tabel 4.12 Hasil Uji Pretest dan Posttest Skor Gerak Shalat

\begin{tabular}{|c|c|c|c|c|}
\hline \multirow{2}{*}{$\begin{array}{l}\text { Keterampilan } \\
\text { Melakukan } \\
\text { Gerak Shalat }\end{array}$} & \multicolumn{2}{|c|}{ Kelompok Eksperimen } & \multirow[b]{2}{*}{$\begin{array}{l}\text { tatistik } \\
\text { Uji }\end{array}$} & \\
\hline & $\begin{array}{l}\text { Pretest } \\
(\mathrm{n}=32)\end{array}$ & $\begin{array}{l}\text { Post test } \\
(n=32)\end{array}$ & & \\
\hline $\bar{x} \pm$ (std.dev.) & $2,38(0,21)$ & $3,25(0,19)$ & & \\
\hline Min. - Max. & $2,00-2,91$ & $2,82-3,82$ & $t=16,832$ & 0,000 \\
\hline
\end{tabular}

Hasil uji secara statistik terhadap keterampilan shalat dengan metode role playing pada anak TK saat pretest dengan posttest menunjukkan perbedaan yang signifikan ( $\mathrm{p}$-value $=0,000<0,05$ ). Hasil pengujian ini menunjukkan bahwa terdapat perubahan yang signifikan pada keterampilan shalat dengan metode role playing pada anak TK setelah mendapat perlakuan.

Terjadi perubahan keterampilan melakukan gerak shalat melalui metode role palying menguat apa yang dikatakan oleh Mulyasa, E, (2004:141) bahwa metode role playing dapat digunakan dalam pengembangan keterampilan dan sikap, tentunya di sini keterampilan melakukan gerak shalat dan sikap sopan santun.

Ditemukan beberapa permasalahan dalam penerapan pembelajaran melalui metode role playing dalam rangka keterampilan melakukan gerak shalat pada anak TK, di antaranya adalah guru masih kikuk dan mengalami kecanggungan dalam menggunakan metode role playing pada keterampilan melakukan gerak shalat di TK, hal ini sebetulnya dapat dimaklumi dikarenakan guru TK masih baru dalam 
penerapan metode role playing. Seharusnya dalam penerapan metode ini guru hendaknya telah benar-benar menguasi metode tersebut

Selain itu keterbatas waktu dalam pelatihan peran bagi pemeran yang berdampak pada kualitas pemeranan yang dilakukan, menurut hemat peneliti bahwa idealnya ada waktu yang cukup dalam pelatihan adegan atau peran yang akan dimainakan sehingga dapat meminimalisir kesalahan adegan atau peran dan guru bisa lebih fokus pada pengamatan pemeranan yang sedang berlangsung.

Adapun anak dalam menyaksikan teman-temannya yang bermain peran sehingga mengganggu jalannya pemeranan dalam penerapan metode role playing sebenarnya dapat diatasi dengan menyampaikan bahwa semuanya akan kebagian dalam memerankan adegan atau peran yang sedang berlangsung, sehingga anak akan memperhatiakan karena adanak akan berpikir bahwa mereka akan memerankan peran yang sama nantinya. Sementara kurang maksimalnya fungsi pengamat dalam penerapan metode role playing, mungkin bisa diatasi dengan cara silang pengamat atau menghadirkan pengamat dari TK lain

\section{SIMPULAN DAN REKOMENDASI}

Setelah berakhirnya penelitian yang dilakukan maka dapat disimpulkan sebagai berikut:

Pada penerapan metode role playing dalam keterampilan melakukan gerak shalat di TK Al-latif Kecamatan Tambang, tidak semua tahapan metode role playing dapat dilaksanakan, di antaranya: tahapan no 6) mendiskusikan dan mengevaluasi peran, dan tahapan no 9) mengkaji kemanfaatannya dalam kehidupan nyata melalui saling tukar pengalaman dan penarikan generalisasi. Hal ini dikarenakan tingkat perkembangan anak yang belum memungkinkan untuk berdiskusi, sebagai gantinya dilakukan tanyajawab antar guru dan anak TK mengenai peran yang baru disaksikan. Terdapat perubahan yang signifikan pada keterampilan melakukan gerak shalat melalui metode role playing, sehingga metode ini dapat digunakan dalam keterampilan melakukan gerak shalat di TK Al-latif Kecamatan Tambang.

Permasalahan yang ditemukan pada penerapan metode role playing dalam keterampilan melakukan gerak shalat adalah sebagai berikut; Guru TK masih kaku dan mengalami kecanggungan dalam menerapkan metode role playing, siswa belum dapat memahami instruksi guru dengan benar dalam peran yang akan dimainkan oleh anak. Siswa ribut karena telalu antusia dalam mengikuti pemebelajaran melalui metode role playing

Adapun yang menjadi rekomendasi sebagai berikut: Kepada Guru TK, bahwa dalam penerapan metode role playing harus melaksanakan semua tahapan penerapan sehingga akan memudahkan guru dalam mencapai tujuan pembelajarannya, terutama dalam keterampilan melakukan gerak shalat.

Dalam pengembangan gerak shalat di TK Al latif Kecamatan Tambang, guruguru harus menjadikan metode role playing sebagai metode pilihan alternatif, karena telah terbukti.

\section{DAFTAR PUSTAKA}


Abbas, A. (1991). KonsepShalatMenurut Al-Qur'an.Jakarta: CV Firdaus

Abdullah.(2003) Shifatus Shalah.(Terjemahan). Solo: At-Tibyan

Aly, HeryNoerdan H. Munzier, S. (2000).WatakPendidikan Islam (CetakanPertama). Jakarta: FriskaAgungInsani.

Anwar. Ahmad, A. (2007). PendidikanAnakDiniUsia. Bandung: Alfabeta

Arikunto, S. (2006).ProsedurPenelitiansuatuPendekatanPraktik.Jakarta: PT RinekaCipta.

Chris Barker, Nancy Pistrang\& Robert Elliot (2002). Research Methods in Clinical Psychology.( $2^{\text {nd }}$ ed.). England: John Wiley \& Sons, LTD Chichester England.

Conny,R. (2008).BelajardanPembelajaranPrasekolabdanSekolabDasar. Jakarta: PT. Macanan Jaya Cemerlang.

Dahlan.(1984). Model-model Mengajar.Bandung; CV Diponegoro.

Daradjat, Z. (2006). IlmuPendidikan Islam (CetakanKe 6). Jakarta: BumiAksara.

Direktoratpembinaan TK dan SD. 2007).PedomanPembelajaranBidangPengembanganPembiasaan di Taman Kanak-Kanak: Jakarta

DirektoratPendidikan Madrasah. (2007) KurukulumRaudhatulAthfal (RA) Model Pembelajaran. Jakarta: DirektorakJenderalPendidikan Islam.

Fajar, Kusuma, A (2008). Hikmahshalatdalamkehidupanumat.Diperolehtanggal 20 maret darifile://localhost/D:/My\%20Study/Thesis/hikmah\%20sholat.mht.

Gintings, A. (2008). EsensiPraktisBelajardanPembelajaran. Bandung: Humaniora.

Hurlock, Elizabeth B. (1980). Developmental Phsychology.(Terjemah). Ed. V. Jakarta :Erlangga

Ibrahim, R danSyaodih, Sukmadinata, N. (2003) PerencanaanPembelajaran.Jakarta: RinekaCipta

Jamaris, M. (2006).Perkembangan Dan PengembanganAnakUsai Taman Kanak-Kanak. Jakarta: Grasindo.

Juntika, Nurikhsan, A(2007). ModulPsikologiPerkembangan. Bandung: UniversitasPendidikan Indonesia. 
Kadir, Nuhuyanan, A. (2002). PedomandanTuntunanShalatLengkap.Jakarta: GemaInsani.

Mahmud, Abdullah, M (2005). FaedahShalatbagikesehatanJasmani, RohanidanMasyarakat. Jakarta: Pustaka Al-Kautsar.

Moeslihatun, R. (1999). MetodePengajaran di Taman Kanak-kanak. Jakarta: RinekaCipta.

Nashiruddin, Albani, M (2008). SifatShalatNabi. Jakarta: Akbar Media EkaSarana.

Nasiruddin, Al-Albani, M. (2000).SifatShalatNabi(Terjemahan). Yogyakarta: Media Hidayah

Samsudin.(2008). PembelajaranMotorik Di Taman Kanak-Kanak. Jakarta: LiteraPrenada Media Group.

Singgih, S(2002).Mengolah Data StatistikSecaraProfesional. Jakarta: PT Elex Media Komputindo

Sudjana, N. (1989). Dasar-Dasar Proses BelajarMengajar.Bandung: SinarBaruAlgensindo.

Syaefudin, U., Rosmini.N (2006).PembelajaranTerpadu. Bandung; UPI Press.

Syamsuddin A.R., danDamaianti, Vismaia S. (2007). MetodePenelitianPendidikanBahasa. Bandung: SekolahPascasarjana UPI dengan PT RemajaRosdaKarya.

Syaodih, Sukmadinata, N. (2005). LandasanPsikologi Proses Pendidikan. Bandung: PT. RemajaRosdakarya. 